\title{
More Prize-Winning Films on Mental Health
}

The latest annual BMA Film Competition attracted 78 entries from Canada, Denmark, Germany, Sweden, USA and the UK; some films on mental health were among the winners.

A silver award went to The Hidden Struggle (colour, $16 \mathrm{~mm}, 25 \mathrm{mins})$. Made in 1981 by Clausen House (California) in association with Pyramid Films, this is a film about the residential care of mentally handicapped adults. It is a very competent production which demonstrates with sympathy and understanding the working and social lives of the residents in a cluster of houses. Details of the treatment programmes are shown and the retarded persons speak for themselves. Intended for professional staff and also for the general public, it can be hired from Harris Films, Glenbuck Road, Surbiton, Surrey, and also from the BMA, Tavistock Square, London.

A Time For Caring (colour, $16 \mathrm{~mm}, 25 \mathrm{mins}$ ) received a bronze award. It was made in 1960 by Aegis Productions (New York) under the medical direction of the Department of Family Psychiatry, Youngstown, Ohio. Its purpose is to motivate nurses who have the care and management of patients suffering from organic brain syndrome. This is effectively and convincingly done by dramatizing some of the problems encountered by a young nurse. The acting is very competent, and the film could have a wider use in other situations dealing with chronic handicap. Distributed by McNeil Laboratories, Spring House, PA 19477, USA, a copy will also be available through the BMA.

Two other films which won bronze awards may be of interest to psychiatrists. Has Anyone Seen Mrs Murrey? (colour, 16mm, 30mins, 1982) was made by Professor V. W. M. Drury and it identifies some of the problems in caring for elderly people. Taking it in Stride: Posittve Approaches to Stress Management (colour, 16mm, 22mins, 1981) encourages people to take control of their lives by presenting a summary of skills for coping with stress. It was made by Spectrum Films (USA). Enquiries for both should be made to the BMA Film Library.

\author{
T. L. Pilkington \\ Convener, \\ A-V Working Group
}

\section{Elections to the Fellowship, 1983}

The following Members have registered as Fellows of the College following their election by the Court of Electors at its meeting on 14 February 1983.

M. F. A'Brook, S. H. Ahmed, J. A. Aitken, L. Arenillas, K. W. Aron, M. Ashraf, M. O. Aveline, C. E. Bagg, L. B. Bartlet, D. R. Benady, R. C. Benians, E. D. Bird, D. W. K. Bird, Jean M. W. Bolt, P. M. A. Bowden, R. A. Bugler, A. A. Campbell, P. G. Campbell, Helen M. Connell, D. F. Craggs, J. R. T. Davidson, M. P. Deva, G. Dickens, M. V. Driver, J. P. Duffy, A. I. Elbey, L. E. J. Evans, K. P. Fink, A. Q. Gardiner, J. W. Gleisner, M. E. Grant, I. Haidar, Zaida M. Hall, A. J. Harbott, P. Hays, Mary K. P. Henderson, T. A. Holding, R. V. Howarth, D. D. Howell, S. C. Jain, P. M. Jefferys, G. Kanakaratnam, H. B. Kedward, A. M. P. Kellam, P. F. Kennedy, D. J. King, S. Kumar, Marian W. Leyshon, S. Lieberman, J. Lister, A. V. P. Mackay, B. L. Mallett, S. G. R. Martens, H. Maxwell, P. R. A. May, Joan McConnell, W. B. McConnell, B. J. McConville, W. McQuaker, D. G. Melville-Thomas, Brenda Morris, M. C. Moss, P. J. Mullin, T. E. Nelson, P. W. Ngui, A. L. Parker, G. M. Petrie, H. Prosen, D. M. Ricks, P. D. Rohde, J. E. Runions, A. Russell, G. G. C. Rwegellera, R. Shulman, A. Skarbek, J. S. Smith, A. A. Sugerman, S. S. Sutherland, B. K. Wharton, J. C. M. Wilkinson, Eluned WoodfordWilliams, N. Wright.

\section{Audio-Visual Working Group}

The Films Sub-Committee of the RMPA, and latterly the Audio-Visual Sub-Committee of the College, has been operative since 1957. There have been considerable changes in these 25 years, both in the technology and in the interests within psychiatry itself. It is clearly desirable that the College continues to be kept informed about this field, maintains its active collaboration with other bodies, and develops its own areas of interest; but it is now felt that these objectives would be more effectively pursued on a less formal basis.

The A-V Sub-Committee has therefore been replaced by an Audio-Visual Working Group, attached to the Education Committee. This Group, widely representative, will work mainly by correspondence and informal meetings, and in the first instance will be particularly concerned with the listing and appraisal of existing A-V material. It will continue to organize presentations at College meetings and collaborative symposia on A-V aids, and stimulate new productions.* It is hoped that it will act as a focus of innovation in audio-visual developments in relation to psychiatry.

I would be pleased to hear from anyone interested in joining the Group, with an indication of their special interests.

T. L. Pilkington Convener, A-V Working Group

*Both the Graves organization and the Psychiatric Rehabilitation Association offer some financial and technical assistance; I would be pleased to forward details. 